\title{
Microcontroller Based Power Factor Correction Using IC L6561
}

\author{
Priya S. Devkar \\ Electronics \& Communication Department, Deogiri Institute of Engineering \& Management Studies, BAMU, \\ Aurangabad, Maharashtra, India
}

\begin{abstract}
Proposed system presents an efficient AC/DC converter with power factor correction by using IC L6561. The Microcontroller 89 s52 used to generate triggering pulses for semi converter based on firing angle control mechanism. Semi converter gives controlled DC output with variable voltage range. IC 16561 based on borderline control techniques used for power factor correction. The objective of proposed system is to give reliable power control over the output of AC to Dc converter and improve the power factor. The major application of this system is for domestic purposes and also can be used in industry purpose.
\end{abstract}

Keywords: Firing angle control; Optoisolator; Semi converter; ZCD; ICL6561; PFC

\section{Introduction}

Now a day there is large demands of electronics devices such as computer, TV etc. These all are required a controlled DC power supply. But due to the nonlinear behavior of the ac to dc converter current distortion occurs at the output and causes low power factor.

Power factor $=$ Actual Power/Apparent Power

The actual power is the power being used in a circuit and apparent power is the power being drawn from the mains. But some additional reactive power is required to perform particular work, and causespower losses. So as to reduce the power losses and to improve the power factor this system proposes Microcontroller based power factor correction by using IC L6561. In proposed system two control methods are used i.e. Borderline current control \& Firing angle control. The Microcontroller based triggering circuitry operates on firing angle control mechanism and generating pulses for semi converter. Power factor correction IC L6561used to correct the power factor value based on borderline current control method. Gate driver and opto isolator circuitry makes proper isolation in between triggering circuit and power circuit. The proposed system gives controlled DC output with wide output voltage range.

\section{Literature Survey}

For controlled power output Shashikant V. Lahade [1] proposes a microcontroller based digital trigger circuit for $\mathrm{AC} / \mathrm{DC}$ converter. In this system a digital trigger mechanism has been used for the control of output power. A programmable pulse train is generated in desired sequence as output of microcontroller. A firing angle control method is used for generating the triggering pulses. This system gives reliable, affordable and accurate power control, but this system does not work on power factor correction. Suja C Rajappanet.al. [2] Describes a bridgeless power factor correction boost converter which results in improved power factor and reduced harmonics content in input line currents as compared to conventional boost converter topology. Bridgeless power factor correction boost converter eliminates the line-voltage bridge rectifier in conventional boost power factor correction converter, so that the conduction loss is reduced. In this system a PWM technique is used for power factor correction.

Nagaranjan M et.al.[3]Proposes PIC microcontroller based power factor correction by using PWM control method. But PWM control method fails to reduce current harmonic distortion. R.Seyezhaiet.al.[4]Describes comparison of various current control technique employed for a bridgeless boost converter for improving the power quality such as peak current, average current mode and borderline current control.This system results input current waveform close to sinusoidal implying high power factor and reduced harmonics for borderline current control. Nonlinear load such as rectifier distort the current drown from the system and causes low power factor. So Sridevi J. [5] presents active power factor correction controller using boost converter. IC L6561is used for power factor correction. IC L6561 operated on Borderline current control mechanism for generating the triggering pulse. This system gives better power factor correction.

Abhinav Sharma et.al.[6] Presents design and development of a single phase TRIAC based Static VAR Compensator for reactive power compensation and power factor correction using PIC (Programmable Interface Circuit) microcontrolling chip. This system is based on firing angle control method for generating the triggering pulses by using PIC microcontroller. Sanjay N. Patel et.al.[7] Proposes a conceptual design of microcontroller based automatic power correction (APFC Relay) for $1-\varnothing$ and $3-\varnothing$ circuit for nonlinear loads. This system is based on firing angle control method.Proposed system uses Firing angle control method for getting variable controlled output voltage and borderline current control method for power factor correction by using IC L6561.

\section{Proposed System}

A scheme that address on building up system as a mention above is presented here as the single phase power factor correction for nonlinear loads with wide output voltage range. The following figure 3 shows the hardware details of the proposed system 


\section{International Journal of Science and Research (IJSR) \\ ISSN (Online): 2319-7064}

Index Copernicus Value (2013): 6.14 | Impact Factor (2014): 5.611

\section{1 ero Crossing Detectors}

The zero crossing detectors provide the zero crossing reference of the line frequency to the trigger circuit.It consists of comparator block using op-amp (OP07). Its output swings to either positive saturation or negative saturation andgiven as interrupt to the microcontroller as shown in following figure 1 and 2.

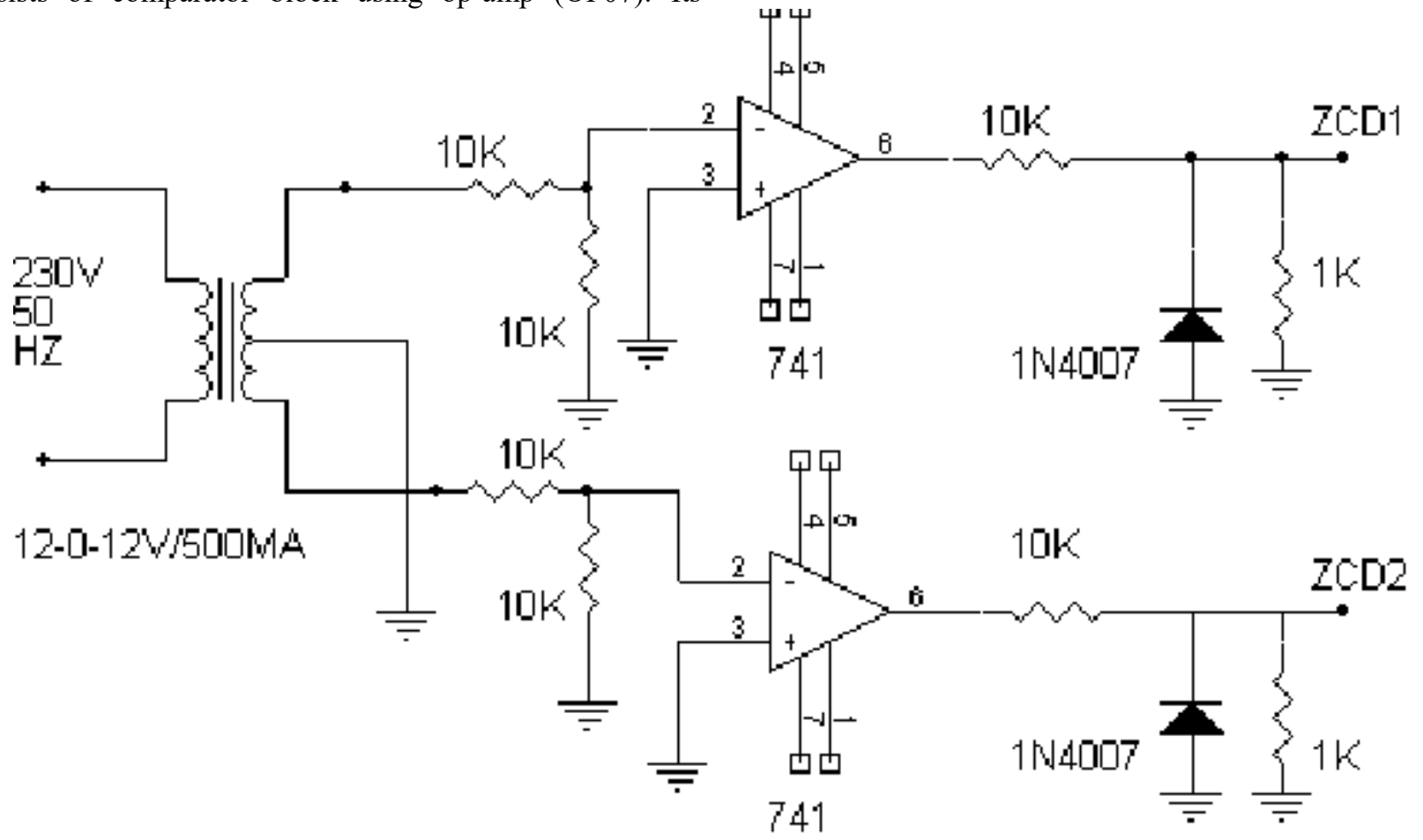

Figure 1: Zero crossing detectors module

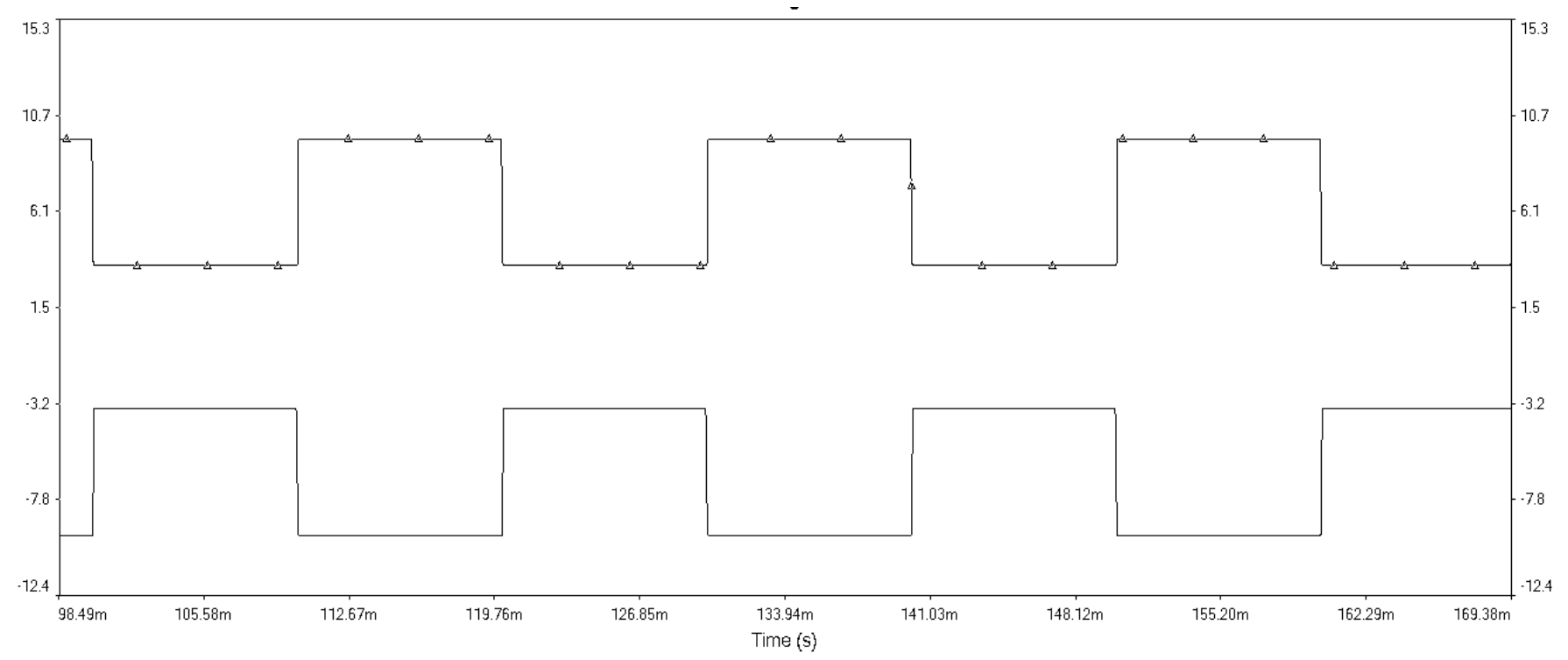

Figure 2: Zero Crossing Detectors Output

\subsection{Analog to Digital Converter}

The ADC is connected to the variable potentiometer for changing the analog voltage form 0 to $5 \mathrm{v}$. Here an 8 bit code values are assign for proportional analog voltage and according to the voltage value the ADC generate the digital count and given to the microcontroller as a reference signal.

\subsection{Microcontroller}

The microcontroller $89 \mathrm{~s} 52$ gets interrupted by ZCD outputs and $\mathrm{ADC}$ reference signal and according to that the microcontroller generates the firing angle and display on the LCD. According to the firing angle the interrupt signal are converted in to firing pulses which controls the semi converters. The microcontroller generates triggering pulse between firing angles $8^{0}$ to $172^{\circ}$.

\subsection{LCD}

The LCDdisplays the firing angle of Triggering pulses. 


\subsection{Buffer Signals}

The Octal buffer offers asynchronous two way data communication between the control and power circuitry.

\subsection{Opto isolator and Gate Driver}

It isolates the control circuitry from the power circuitry. Signal amplifier (TIP-122)darling tone pair transistor is used for current boosting.

\subsection{Semi converter}

In semi converter two MOSFETs are connected in parallel operating for both positive and negative half cycle respectively. According to the firing angle control the semi converter gives the controlled output with variable voltage range.

\subsection{Automatic Power Factor Correction IC L6561}

IC L6561 based on borderline current control method used for power factor correction. IC L6561controls the power MOSFET according to the reference signal getting from microcontroller.

\subsection{Software Used}

The software of the whole system was developed using embedded ,CC.

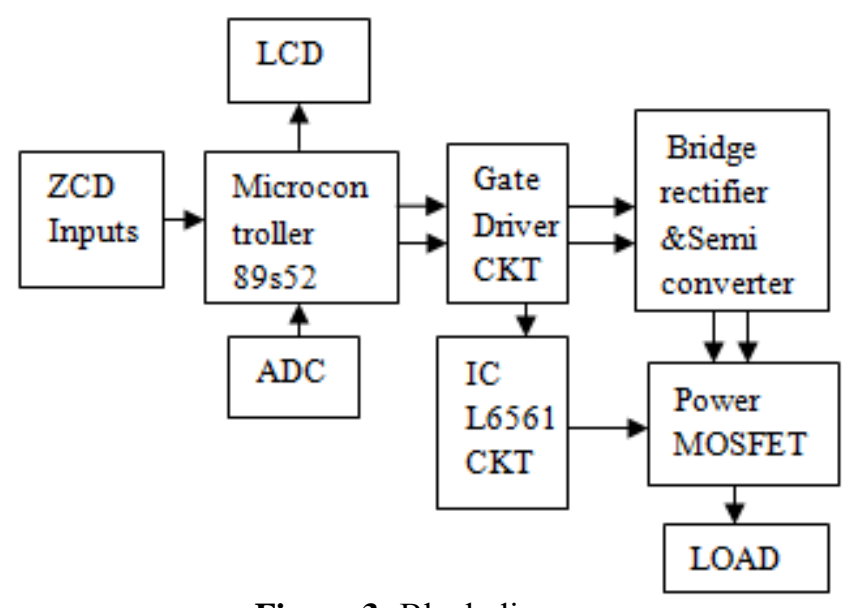

Figure 3: Block diagram

\subsection{Generation of Triggering Pulse for Semi Converter}

The microcontroller gets interrupted by zero crossing detectors (falling edge of Square wave) and the latest value of ADC output. According to the ADC reference value the triggering pulses are generated. The ADC output value range in between 0 to $5 \mathrm{v}$ count which is used to control firing angle $0^{\circ}-180^{\circ}$. Suppose , $\mathrm{p}^{\text {ee }}$ is latest output value of ADC and ,$\alpha^{e c}$ is the firing angle the relationship in between the firing angle and the ADC output is given in equation 1.

$\alpha=\mathrm{p} / 0.0277$ (1)

At firing angle $90^{\circ}$ the following diagram 4 shows the triggering pulses generated by the microcontroller for both MOSFET 1\& MOSFET 2.The total time equals to on time plus off time for triggering pulse is $10 \mathrm{msec}$.Following figure 6 shows the flow chart of triggering pulse generation.

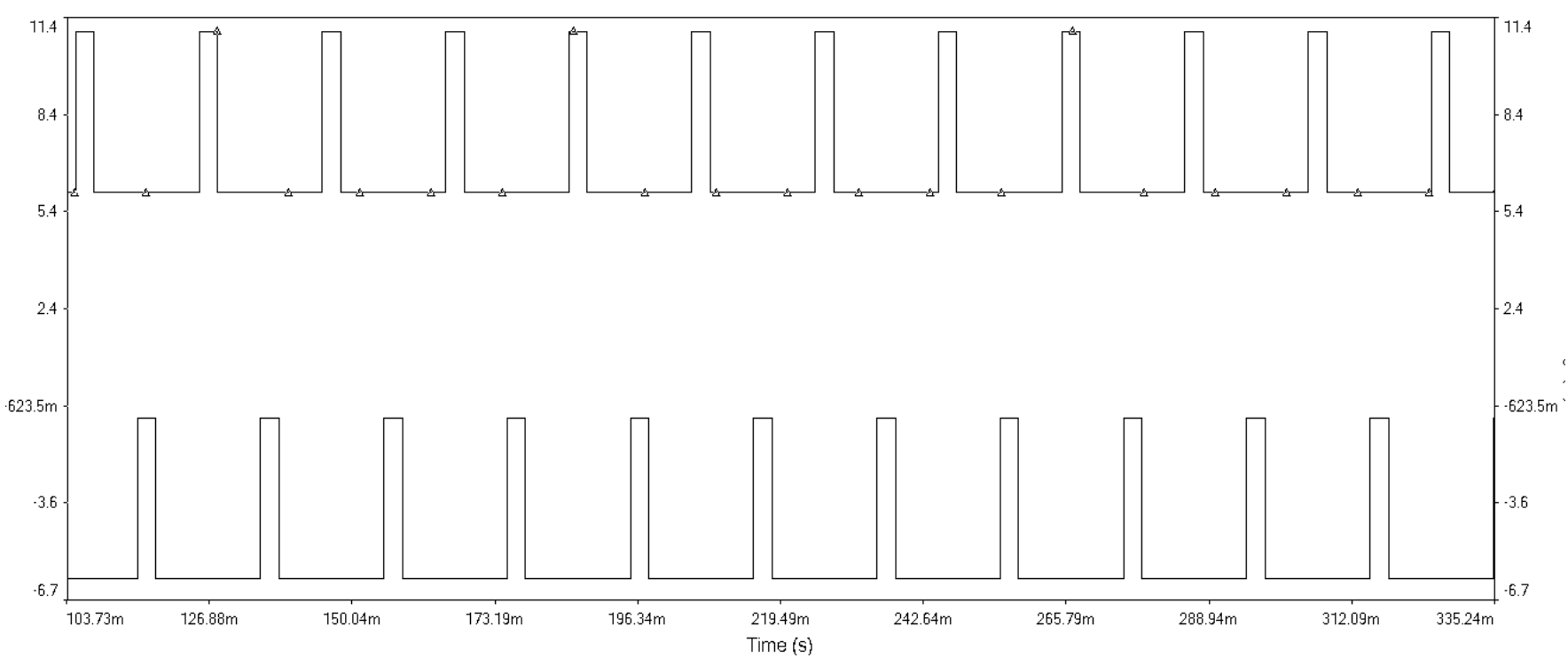

Figure 4: Triggering Pulses for Semi converter 
International Journal of Science and Research (IJSR)

ISSN (Online): 2319-7064

Index Copernicus Value (2013): 6.14 | Impact Factor (2014): 5.611

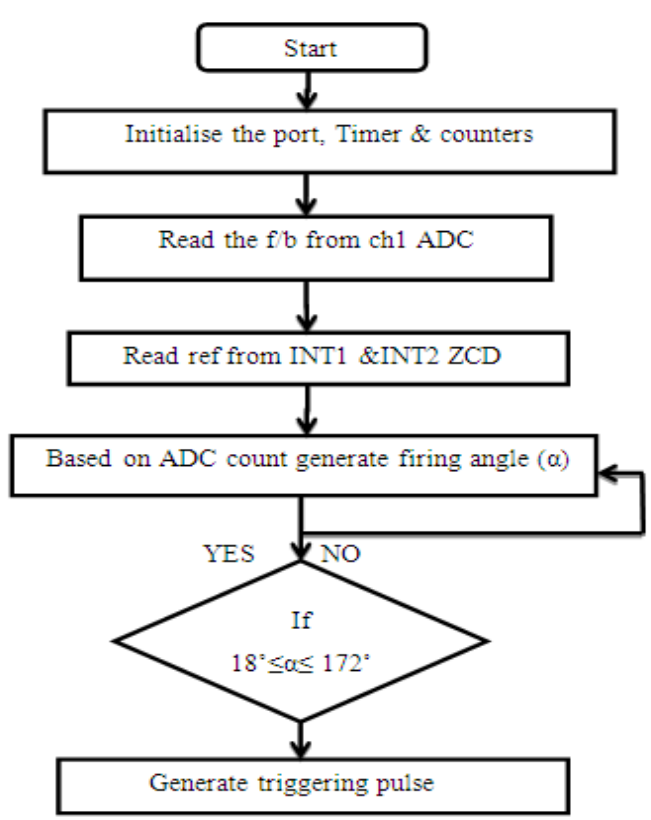

Figure 5: Flow Chart of Triggering Pulse Generation

\section{Result \& Discussion}

The hardware and software part of the proposed system is fully tested and demonstrated. For the application purpose RL load i.e.60 watt bulb with 0.25 HP DC shunt motor. Proposed system is fully operated on firing angle above $8^{\circ}$ and below $172^{\circ}$. The output is tested here according to the brightness value of the bulb and speed of motor to its rated value.

The power factor correction automatically starts from firing angle $90^{\circ}$. The CRO shows a waveform which is varying according to firing angle across the load. The firing angle can be calculated theoretically from the waveform shown by the CRO. For power factor calculation following formula is used.

Where $\alpha=\mathrm{n} / \mathrm{p} * 180$

Power factor $=\cos \alpha,(2)$

The following table shows the theoretical and practical calculations for the RL load.

Table 1: Theoretical and Practical Calculation for RL Load

\begin{tabular}{|c|c|c|c|c|c|c|}
\hline $\begin{array}{c}\text { Sr. } \\
\text { no. }\end{array}$ & $\begin{array}{c}\text { Triggering } \\
\text { angle }\end{array}$ & $\begin{array}{c}\text { Conduction } \\
\text { period (n) }\end{array}$ & $\begin{array}{c}\text { Total } \\
\text { period(p) }\end{array}$ & $\mathrm{V}_{\mathrm{dc}}$ & $\alpha=\mathrm{n} / \mathrm{p}^{*} 180$ & $\mathrm{PF}=\cos \alpha$ \\
\hline 1 & $18^{\circ}$ & 0.2 & 4.8 & 6.8 & $9^{\circ}$ & 0.985 \\
\hline 2 & $30^{\circ}$ & 0.6 & 4.8 & 26.4 & $22.5^{\circ}$ & 0.923 \\
\hline 3 & $40^{\circ}$ & 1 & 4.8 & 51.5 & $37.5^{\circ}$ & 0.793 \\
\hline 4 & $50^{\circ}$ & 1.2 & 4.8 & 81.3 & $45^{\circ}$ & 0.707 \\
\hline 5 & $60^{\circ}$ & 1.6 & 4.8 & 120.7 & $60^{\circ}$ & 0.5 \\
\hline 6 & $70^{\circ}$ & 1.8 & 4.8 & 158.6 & $67.5^{\circ}$ & 0.382 \\
\hline 7 & $80^{\circ}$ & 2 & 4.8 & 201 & $75^{\circ}$ & 0.258 \\
\hline 9 & $100^{\circ}$ & 2.6 & 4.8 & 240.3 & $97.5^{\circ}$ & 0.130 \\
\hline 10 & $120^{\circ}$ & 3.1 & 4.8 & 269 & $110^{\circ}$ & 0.5 \\
\hline 11 & $140^{\circ}$ & 3.7 & 4.8 & 273 & $140.5^{\circ}$ & 0.79 \\
\hline 12 & $172^{\circ}$ & 4.6 & 4.8 & 274 & $170.5^{\circ}$ & 0.9814 \\
\hline
\end{tabular}

Figure 5 shows the Simualtion results of the ac/dc converter with power factor correction circuitry.

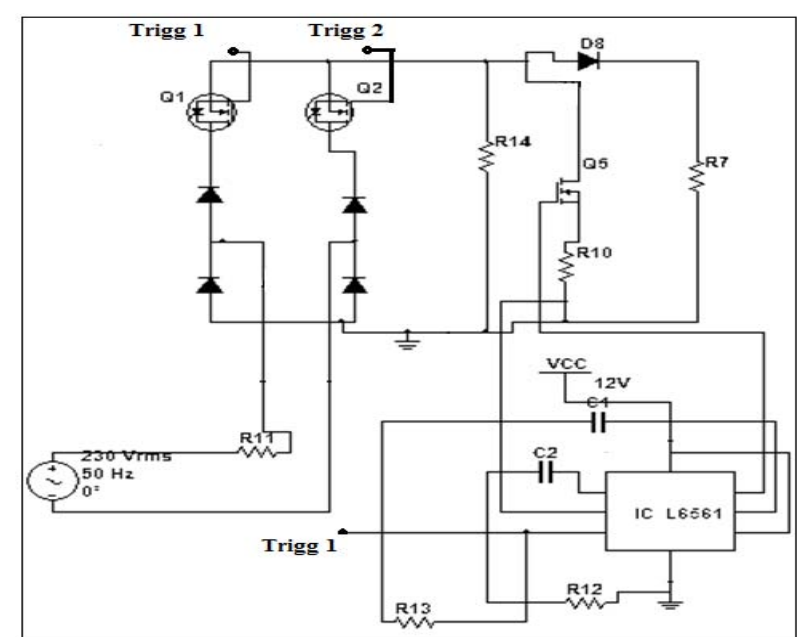

Figure 6: Simulation of Proposed System

Figure 7 and 8 shows the voltage and current wave form for $\mathrm{R}$ and RL load.

\subsection{For R load}

For R load Power Factor $=98.99 \%$

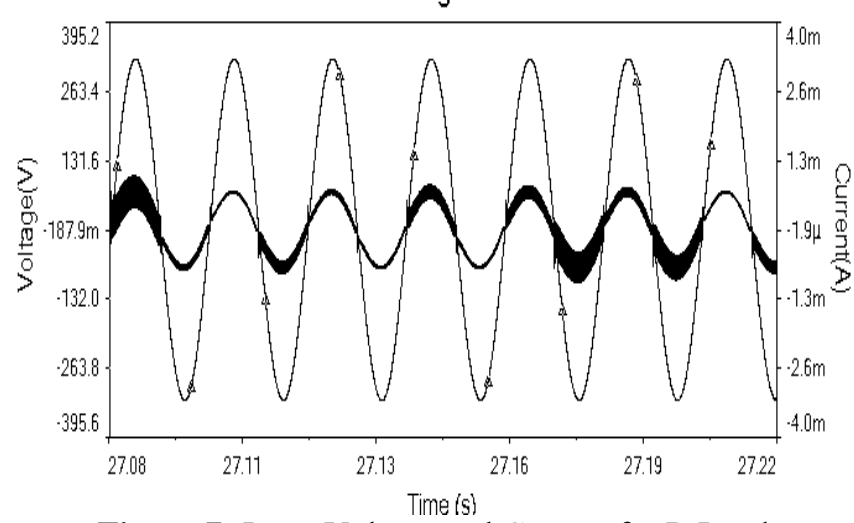

Figure 7: Input Voltage and Current for R Load

\subsection{For R-L Load}

Power Factor $=97.89 \%$

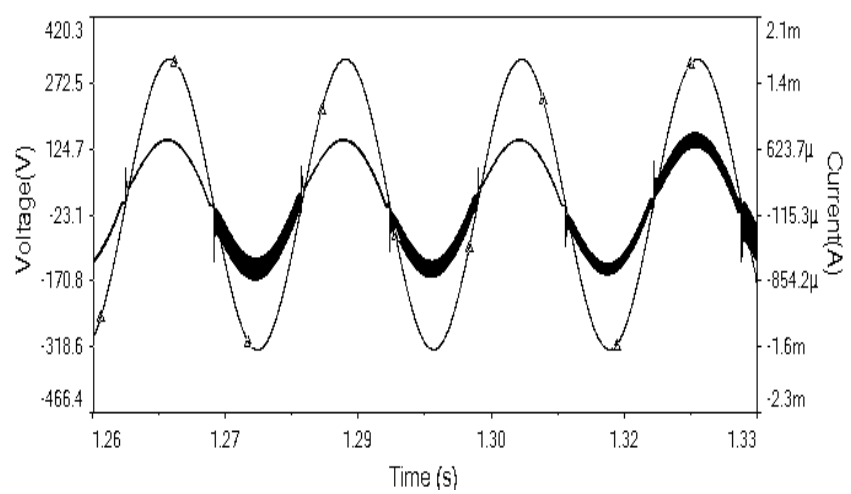

Figure 8: Input Voltages and Current for R-L Load

Following figure 9 shows the hardware circuitry and its setup for $\mathrm{R}$ load at $140^{\circ}$ firing angle and figure 10 shows the conduction angle of load on CRO. 


\section{International Journal of Science and Research (IJSR) \\ ISSN (Online): 2319-7064}

Index Copernicus Value (2013): 6.14 | Impact Factor (2014): 5.611

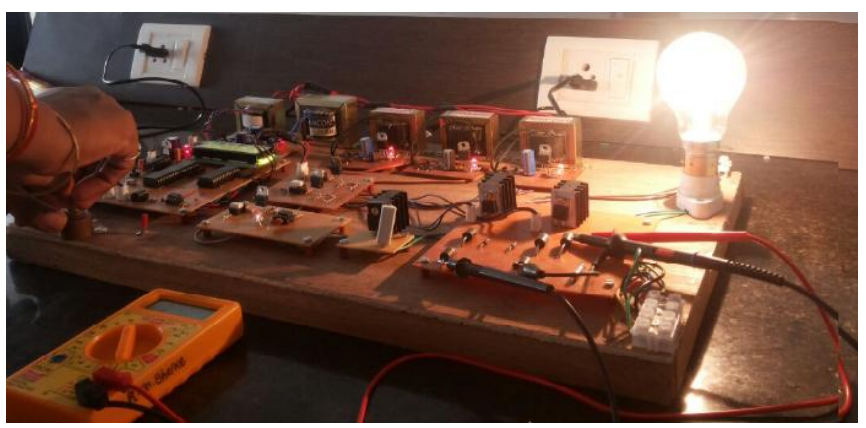

Figure 9: Complete hardware circuitry

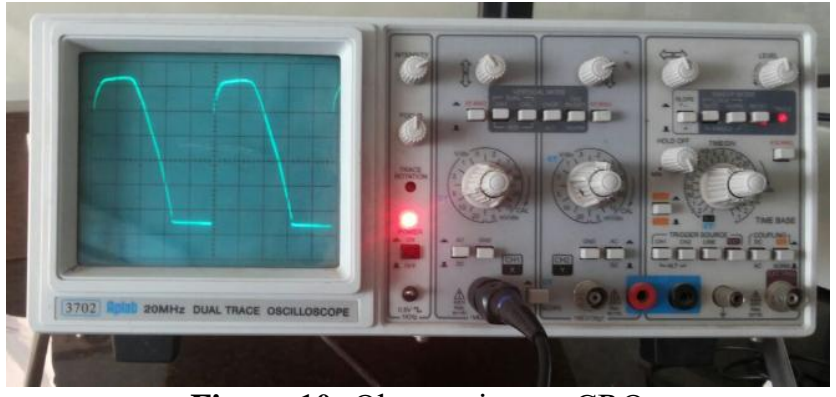

Figure 10: Observation on CRO

\section{Relevance of Project}

Proposed system can be used in Industry. Proposed system reduces the size and cost required to maintain the power factor value and also this system is useful in home appliances.

\section{Conclusion}

Proposed system presents a technique for single phase power factor correction with variable output voltage. This system described two controlling methods called firing angle control and borderline current control for PFC and controlled DC drive output. Experimental results for resistive and resistive inductive load were presented. Proposed system reduces the total harmonic distortion, conduction loss, communication losses etc. This system design requires components which are very cheap and easily available. Controlled DC drive output with power factor correct ion is perfect solution to give controlled AC/DC converter. This system gives power factor up to 0.98 .

\section{References}

[1] FabinaPottkeret.al. "Power Factor Correction of Non Linear Loads Employing a Single Phase Active Power Filter",IEEE paper, 1997.

[2] Abhinav Sharma et.al. "PIC Microcontroller Based SVC Foe Reactive Power Compensation and Power Factor Correction", International Journal of Advanced Research in Computer Science andsoftware Engineering, Vol. 3, Issue.9,September 2013.

[3] B.C. Kok et.al. "A Conceptual Design of Microcontroller-Based Power Factor Corrector Circuit", Malaysian Technical Universities Conference on Engineering and Technology June 2009.

[4] Hye-Yeon Lee et.al. "Single-Phase Active Power Filter Design Using EMTP Simulation", International
Conference on Power Systems Transients (IPST2009) in Kyoto Japan ,June 2009

[5] Shashikant V Lahadeet.al. "Microcontroller based Digital Trigger Circuit for Converter" DOI: 02.PEIE.2014.5.510 Association of Computer Electronics and Electrical Engineers 2014.

[6] Nagaranjan. M et.al. "Optimal Power Factor Correction For Inductive Load Using PIC", International Conference On Modeling, Optimization And Computing, pp.737-744, June 2012.

[7] José A. Cobos et.al. "Single Phase Power Factor Correction: A Survey", IEEE Transactions on Power Electronics, Vol. 18, No.3, may 2003.

[8] Sanjay N. Patel et.al." Thyristorised Real Time Power Factor Correction", International Journal of Engineering Research and Technology", Vol. 2, Issue.3, march 2013.

[9] A. A. Mamunet.al. "Design and Implementation of Single Phase Inverter", International Journal of Science and Research, Vol. 2, Issue.2, February 2013.

[10] PenkeSriniwaset.al. "Power Factor Correction Of Linear And Nonlinear Loads Employing A Single Phase Active Power Filter Based On A Full Bridge Current Source Inverter Controlled Through The Sensor Of The AC Mains Current", International Journal Of Science And Technology Research, Vol. 2, Issue.4, pp.211-215, April 2013.

[11] P. VijayaPrasunaet.al. "Improvement in Power Factor \& THD Using Dual Boost Converter", International Journal of Engineering Research and Applications, Vol. 2, Issue.4, pp.2368-2376, July-August 2012.

[12] Chen zhou et.al, "Design Trade-Off in the Boost Power Factor Correction Circuits with Peak and Average Current Mode Control", Delta power electronics lab. Inc., pp.209-219, May 1992.

[13] Suja C Rajappanet.al. "An Efficient AC/DC Converter With Power Factor Correction",International Journal of Emerging TechnologyAnd Advanced Engineering, Vol. 3, Issue. 3, pp.815-820, March 2013.

[14] R. Seyezhaiet.al. "Analysis of Current Control Techniques on Bridgeless Interleaved Boost DC-DC Converter to Improve Power Quality", International Journal Of Scientific Research in Computer Science And Engineering, Vol. 1, Issue. 4, 2013.

[15] Regan Zane et.al. "A Mixed-Signal ASIC Power Factor-Correction Controller for High Frequency Switching Rectifiers", National science foundation, 1998.

[16] Sridevi J., "A New Active Power Factor Correction Controller using Boost Converter", Research Journal of Engineering Sciences, Vol.2 (8), August 2013.

[17] Rahul Sharma et.al. "Simulation and Analysis of Power Factor Correction in Electric Control System for Metal Halide High Intensity Discharge Lamps", Advance in Electronic and Electric Engineering, Vol. 4, No.2, pp.185-192, 2014.

[18] A. Karaarslanet.al., "The Analysis of AC_DC Boost PFC Converter Based On Peak and Hysteresis Current Control Techniques", International Journal on Technical and Physical Problems of Engineering, Vol.3, Issue. 7, No.2,pp 100-105, June 2011.

[19] H. Z. Aaziet.al. "Review Of Passive and Active Circuits for Power Factor Correction In Single Phase, 


\section{International Journal of Science and Research (IJSR) \\ ISSN (Online): 2319-7064}

Index Copernicus Value (2013): 6.14 | Impact Factor (2014): 5.611

Low Power AC-DC Converters", International Middle East Power Systems Conference, December 2010.

[20] Zhilliang Zhang et.at. "A Digital Adaptive Discontinuous Current Source Driver For HighFrequency Interleaved Boost PFC Converters", IEEE Transactions on Power Electronics, Vol.29, No.3, March 2014.

[21] Yong-Wook Kim et.al. "A Novel Soft Switched Auxiliary Resonant Circuit of A PFC ZVT_PWM Boost Converter foran Integrated Multi-Chip Power Module Fabrication", IEEE, 2013.

[22] Vaddi Ramesh et.al. "Quasi Active Power Factor Correction Scheme for High Efficiency Ac/Dc", International Journal of Modern Engineering research,Vol.3, Issue.3, pp. 1739-1747, May-June 2013.

[23] S. B. Mehta, Dr. J. A. Makwana, "Power factor improvement of SMPS using PFC Boost converter" International Journal of Application or Innovation in Engineering \& Management, Vol. 3, Issue. 4, pp.299304, April 2014.

[24] L. Rossettoet.al. "Control Techniques for Power Factor Correction Converters", University of Padova, Italy.

[25] Tirthraj Sen et.al. "Design and Implementation of Firing Circuit for Single phase converter", International Journal of Computer and Electrical Engineering, Vol.3, No. 3, June 2011.

[26] Anitha. U et.al. "Ac to Dc Conversion Using Active PFC", International Journal of Modern Engineering Research, Vol.2, Issue.6, pp.4220-4223, Nov-Dec 2012.

[27] K. Georgakaset.al. "Power Factor Improvement of an AC-Dc Converter via Appropriate sPWM Technique", Mediterranean Conference on Control and Automation, July 2007.

[28] Tanmoychakraborty et.al. "Phase Angle Measurement using PIC Microcontroller with Higher Accuracy", International Journal of Emerging Technology and Advanced Engineering, Vol. 4, Issue.7, April 2014

\section{Author Profile}

Priya S. Devkar received the BE degree in Electronics and telecommunication from BAMU university, Aurangabad, India. 